\title{
Nerve damage in leprosy: an epidemiological and clinical study of 396 patients in west Nepal - Part 1. Definitions, methods and frequencies
}

\author{
W. H. VAN BRAKEL* \& ISHWAR B. KHAWAS \\ Green Pastures Hospital, P.O. Box 28, Pokhara, Nepal
}

Accepted for publication 28 February 1994

Summary A historic cohort study was performed to determine the prevalence and incidence rates of nerve function impairment (NFI) as demonstrated by sensory testing with a nylon monofilament and standard tests of motor function. The records of 396 new leprosy patients registering at Green Pastures Hospital, Pokhara, between January 1988 and January 1992 were analysed. The mean follow-up period was 21 months.

In all, $36 \%(141 / 396)$ of patients had either sensory or motor function impairment at their initial examination. For each nerve the prevalence of sensory and motor impairment is reported separately. The posterior tibial nerve was the most frequently affected (sensory) nerve $(21 \%)$. Sensory impairment of the ulnar nerve was found in $17 \%$ of the patients; $8.8 \%$ had sensory impairment of the median nerve. The overall incidence rate of motor function impairment was $7 \cdot 5(5 \cdot 4-10)$ per 100 person years at risk (PYAR). Sensory impairment had a significantly higher rate of $13(10-17) / 100$ PYAR (rate ratio $(1.8(1 \cdot 2-2 \cdot 7), p=0 \cdot 0076)$. $\mathrm{Bl}$ patients had a significantly higher incidence rate of nerve function impairment than BT patients (rate ratio 2.3 (1.4$3 \cdot 7), p=0 \cdot 006)$. Altogether $152 / 396(39 \%)$ of the patients required corticosteroid treatment for 'recent' or 'acquired' impairment, and 78 of the patients $(20 \%)$ developed severe nerve function impairment during or after antileprosy treatment. Analysis of potential risk factors for nerve function impairment showed a significant association with the extent of clinical disease expressed as the number of body areas (out of 9 ) with primary or secondary signs of leprosy (rate ratio 5.0 (1.5-17), $p=0.0091)$.

It was concluded that nerve function impairment is a serious problem, often occurring during or after multidrug therapy. The extent of clinical disease expressed as a count of body areas involved, or of skin or nerve lesions may identify patients who are at increased risk of nerve damage.

* Correspondence: c/o INF, PO Box 5, Pokhara, Nepal. 


\section{Introduction}

Leprosy is a disease of the peripheral nervous system and most of the serious complications are due to peripheral neuropathy. ${ }^{1-3}$ As Naafs stated: 'Leprosy would be a rather innocent skin disease were it not for the nerve damage and subsequent loss of sensation and muscle power and secondary ulcerations and deformities, which make the leprosy patient an outcast from society. ${ }^{4}$

Mycobacterium leprae is the only known bacillus able to invade the peripheral nervous system. It is said to be the most common cause of treatable peripheral neuropathy in the world, ${ }^{5}$ but there are surprisingly few studies of the epidemiology of peripheral neuropathy in leprosy. Amongst these are reports from Bell-Krotoski ${ }^{6}$ on 'Nerve Involvement in Leprosy', McLeod et al. ${ }^{7}$ on nerve conduction velocity results, Duncan $\&$ Pearson ${ }^{8}$ describing nerve function impairment (NFI) among pregnant and lactating women, and Becx-Bleumink et al. ${ }^{9,10}$ on nerve damage detected among control programme patients.

Despite much basic neuropathological research in the 1960s, 1970s and early 1980s, particularly by Weddell et al., ${ }^{11}$ Boddingius, ${ }^{12-14}$ Antia et al., ${ }^{15-18}$ Dastur et al., ${ }^{19,20}$ Chopra et al., ${ }^{21} \mathrm{Job}^{22}$ Sabin $^{23,24}$ and Swift, ${ }^{25}$ many clinicoepidemiological questions remain unanswered. These include defining methods of detecting treatable neuropathy, and of preventing neural impairment, as well as means of improving the treatment of neuropathy of recent onset.

Green Pastures Hospital (GPH) is a 100-bed mission hospital in Pokhara, West Nepal, run by the International Nepal Fellowship (INF) under its Leprosy Control Project (LCP), a joint project with His Majesty's Government/Nepal (HMG/N). GPH is the main leprosy referral hospital for the West of Nepal. Good record keeping with fairly standardized methods of assessment have provided data for this retrospective study of the incidence of peripheral neuropathy and reactions in leprosy.

The aims of the present study were to determine:

the prevalence and classification of neural impairment by age and sex, and in specific nerves, at the time of registration;

the incidence rate of neural impairment, occurring during and after anti-leprosy treatment; and

to identify risk factors which are of prognostic value.

\section{Definitions}

Considerable difficulty in studying the peripheral neuropathy in leprosy, and in comparing the results of treatment, is caused by confused terminology and incomplete reports of the methods used (Charosky et al. ${ }^{3}$ ). Unfortunately these defects have persisted. To facilitate comparison with other related studies, the terms used are defined below.

\section{NERVE INVOLVEMENT}

May be defined as 'anything from the presence of a leprosy bacillus in a nerve to the total 
destruction of the nerve. ${ }^{26}$ In the former case the nerve is affected before this can be detected by ordinary physical examination. ${ }^{7,27}$

\section{PERIPHERAL NEUROPATHY}

A general neurological term indicating, "Any disorder that causes structural damage to nerve fibres within the peripheral nervous system' ${ }^{28}$ It does not indicate the aetiology or nature of the disorder or disease. Early in the disease process the 'damage' may be functional rather than structural.

\section{NERVE DAMAGE}

An imprecise but common term for 'neuropathy', which is also used in relation to trauma. Here it indicates clinical or subclinical damage to a nerve, whether reversible or irreversible.

\section{NEURITIS}

A condition in which inflammatory cells are found in the nerve.

\section{ACUTE NEURITIS}

A clinical term, used here to mean: acute inflammation of a peripheral nerve trunk detectable by swelling and/or functional impairment (NFI, see below) with spontaneous nerve pain and/or nerve tenderness on palpation. Nerve pain or tenderness may or may not be accompanied by paraesthesia.

\section{SILENT NEUROPATHY (SN)}

A clinical term used for neuropathy with neural impairment but without the other clinical signs and symptoms of acute neuritis. In this paper it refers to those episodes of neuropathy that cause clinical nerve damage within a period of days or weeks and not to the chronic destructive neuropathy of leprosy.

NERVE FUNCTION IMPAIRMENT (NFI)

Clinically detectable impairment of motor, sensory or autonomic function.

\section{NERVE PAIN}

Spontaneous pain in the distribution of a peripheral nerve trunk either at rest or during movement of the affected limb.

\section{NERVE TENDERNESS}

Pain in a peripheral nerve trunk elicited by palpation of the nerve, which was considered to be significant only if it was spontaneously mentioned by the patient or if it could be 'seen' on the patient's face. 


\section{PARAESTHESIA}

Symptoms of tingling, 'pins and needles', burning or 'electrical' sensations in areas supplied by the affected peripheral nerve.

\section{ANAESTHESIA OR HYPOAESTHESIA}

Complete or partial impairment of tactile sensibility.

\section{VOLUNTARY MUSCLE TESTING (VMT)}

A manual test assessing the strength of individual muscles or groups of muscles in the upper and lower extremities.

\section{SENSORY TEST (ST)}

Use of this term includes the 'ballpen test' or use of a piece of thin paper, a feather, a wisp of cottonwool or nylon (mono)filaments, for light touch or the 'pin-prick test' for pain sensation. ${ }^{29}$ It would be preferable to use the name of the actual test used.

\section{SENSIBILITY TESTING}

The testing of any sensory modality. The following separate modalities are nowadays recognized: static touch, moving touch/vibration sense, pain, and temperature.

\section{IMPAIRMENT}

This is defined as, 'Any loss or abnormality of psychological, physiological, or anatomical structure or function. 30

\section{DISABILITY}

'Any restriction or lack (resulting from impairment) or ability to perform an activity in the manner as within the range considered normal for a human being' ${ }^{30}$

\section{HANDICAP}

'A disadvantage for a given individual resulting from an impairment or disability, that limits or prevents fulfilment of a role that is normal, depending on age, sex and social and cultural factors for the individual. ${ }^{30}$

\section{DEFORMITY}

Secondary structural changes of the eye, hand or foot resulting from impairment of 
sensory, autonomic and/or motor nerve function: joint stiffness, bone absorption, and mechanical imbalance such as 'clawing'. ${ }^{16}$

\section{Methods}

OUTCOME MEASURES

The number of patients with peripheral neuropathy as evidenced by clinical signs of motor and/or sensory impairment.

The number of patients developing nerve function impairment at any stage during or after treatment.

The association between leprotic neuropathy and age, sex, classification, extent of disease (no. of skin lesions, nerves and body areas involved in the disease), phenolic glycolipid-1 (PGL-1) serology results and antileprosy treatment regimens (multidrug therapy (MDT) vs dapsone (DDS) monotherapy).

\section{DIAGNOSIS AND CLASSIFICATION}

Methods of diagnosis, classification, using both the Ridley-Jopling classification, as well as our 'body area classification system', laboratory examinations and histology have been described in detail in a previous paper. ${ }^{31}$

\section{DEFINITION OF NERVE FUNCTION IMPAIRMENT (NFI)}

A patient was considered to have nerve function impairment if there was a deterioration of $>2$ points in his VMT score, or 2 points or more in his TST score compared to the previous result. NFI of less than 6-month's duration was recorded as 'recent', while impairment of longer duration was recorded as 'old'. If no previous VMT and TST results were available the patient's history was used to determine whether the impairment was 'recent' or 'old' (using the same numeric criteria for VMT/TST deterioration as mentioned above).

\section{NERVE FUNCTION ASSESSMENT (NFA)}

A NFA was done by either of 2 trained physiotechnicians at the first examination, at every visit as an outpatient, at annual examinations during treatment and after release from treatment. For patients receiving treatment for a reaction or nerve function impairment that was performed fortnightly.

\section{VOLUNTARY MUSCLE TEST}

A full VMT was performed using the modified MRC scale ${ }^{32}$ as described by Brandsma. ${ }^{33}$ The VMT score consisted of the sum of individual scores $(0-5 ; 0$, paralysed; 5 , normal strength) for certain muscles innervated by the:

Facial nerve; orbicularis oculi (only) - max score 5: ulnar nerve; first dorsal interosseus ('index finger out') and abductor digiti minimi ('little finger out') — max score 10: median 
nerve; abductor pollicis brevis and opponens pollicis ('thumb up')—-max score 10: radial nerve; extensor carpi ulnaris ('wrist up') and extensor digitorum communis (extension of metacarpophalangeal joints) - max score 10: lateral popliteal nerve; extensor hallucis longus and peroneus longus and brevis ('lateral foot up')—-max score; 10.

If any particular muscle could not be tested, e.g. because of joint stiffness or previous surgery, or if test data were not available for any particular follow-up time, the other findings from that occasion were excluded from the analysis.

\section{TOUCH SENSIBILITY TEST (TST)}

Touch sensibility of skin sites (see below) innervated by the ulnar and median nerves was tested using a nylon monofilament giving a force of approximately $10 \mathrm{~g}$ when pressed until it bent. The result was recorded as 'felt' or 'not felt' for each of the sites mentioned below. If the patient sometimes felt the touch and sometimes not, the result was recorded as 'partial'. Touch sensibility of the posterior tibial nerve was tested in a similar way using a thicker monofilament, giving a force of about $75 \mathrm{~g}$. The TST score consisted of the sum of touch sensibility test scores given for individual sites (2, monofilament felt; 1 , doubtful; 0, monofilament not felt); the number of sites depending on the nerve tested:

Ulnar nerve; 3 sites on the pulp of the little finger, over the MCP 5 joint and on the hypothenar eminence respectively-max score 6 : median nerve; 4 sites on the pulp of the thumb, over the MCP 2 joint, the pulp of the index and middle finger respectively-max score 8: posterior tibial nerve; 10 sites on the footsole: on the tip of each toe, over the MTP 1 and 5 joints, the instep, the lateral border and the heel-max score 20 .

If there was an ulcer on the test site a score of 0 was given for that site. If the number of sites for any particular nerve was not complete, e.g. if a digit was missing, the score was recorded as a missing value. Missing data were handled as described above.

\section{CRITERIA FOR INCLUSION AND EXCLUSION OF PATIENTS}

All new, previously untreated patients who registered for treatment in the GPH during the period January 1988 to January 1992 were included in the study. Patients whose treatment for reaction/neuropathy was started elsewhere more than 1 week before arrival the GPH were excluded.

\section{STATISTICAL METHODS}

The significance of the difference between proportions was tested using the Standard Normal Deviate (SND) for unpaired samples and McNemar's paired $\chi^{2}$ test for paired samples. ${ }^{34}$ The significance of an association between nerve function impairment and any risk factor was examined with Cox' proportional hazards regression and is expressed as rate ratios. Incidence rates were calculated as the number of patients developing new nerve function impairment during the follow-up period divided by the cumulative person years at risk. Patients were censored as soon as new impairment had occurred. For patients for whom the exact time between registration and onset of neural impairment was not known it was assumed that it had occurred half way during their follow-up 
period. Patients lost to follow-up due to death, defaulting or transferral only contributed person years to the denominator for as long as they were still followed up. Significance of the difference between rates was calculated using the appropriate SND test. A $p$-value of less than $5 \%$ was used as level of statistical significance. For the most important proportions or ratios the $95 \%$ confidence interval is given in parentheses after the ratio, e.g. $4 \cdot 1(2 \cdot 1-8 \cdot 2)$, means that there is $95 \%$ chance that the ratio actually lies between the values $2 \cdot 1$ and $8 \cdot 2$. We used Epi Info Software, version $5 \cdot 01,{ }^{35}$ for analysis.

\section{Results}

PATIENTS

We included 396 new patients in the study. The mean age was 41 years (range 2-88, standard deviation 16); 277/396 were male. Only 335 patients were available for followup (the remainder were transferred elsewhere after diagnosis). Their average follow-up time was 21 months (range 1-49), 71 patients were taking dapsone monotherapy, 256 and 68 were on or had been released from WHO multidrug therapy (MDT), ${ }^{29}$ for multibacillary and paucibacillary patients, respectively, and 1 patient was on a different multidrug regimen.

\section{NERVE FUNCTION IMPAIRMENT}

Table 1 shows the prevalence at first examination of motor and sensory impairment in the Ridley-Jopling classification subgroups. This is illustrated in Figure 1. The only 2 TT and 7 BB patients had no NFI and are therefore not included in Figure 1. In all patients, except the pure neuritic (PN) patients, the prevalence of sensory impairment was a little higher than motor impairment (overall $29 \%$ vs $24 \%$, respectively). This difference was not significant at the $5 \%$ level ( $p=0 \cdot 11$, SND test).

Incidence rates are shown in Table 2 and Figure 2. BL patients had a significantly higher rate than BT patients (29 vs 12/100 person years at risk (PYAR), rate ratio $2 \cdot 3$

Table 1. Prevalence of nerve function impairment at first registration in 396 previously untreated patients at Green Pastures Hospital

\begin{tabular}{|c|c|c|c|c|c|c|c|}
\hline \multirow[b]{2}{*}{ Classification } & \multicolumn{3}{|c|}{ Motor impairment } & \multicolumn{2}{|c|}{ Sensory impairment } & \multicolumn{2}{|c|}{ Either } \\
\hline & $\begin{array}{c}\text { Total } \\
\text { patients }\end{array}$ & $\begin{array}{l}\text { Number } \\
\text { affected }\end{array}$ & $\begin{array}{c}\text { Prev }(\%) \\
(95 \% \mathrm{Cl})^{\mathrm{a}}\end{array}$ & $\begin{array}{l}\text { Number } \\
\text { affected }\end{array}$ & $\begin{array}{l}\text { Prev (\%) } \\
(95 \% \mathrm{Cl})\end{array}$ & $\begin{array}{l}\text { Number } \\
\text { affected }\end{array}$ & $\begin{array}{l}\text { Prev (\%) } \\
(95 \% \mathrm{Cl})\end{array}$ \\
\hline TT & 2 & 0 & & 0 & & 0 & \\
\hline BT & 202 & 49 & $24(18-30)$ & 59 & $29(23-35)$ & 69 & $34(28-41)$ \\
\hline BB & 7 & 0 & & & & & \\
\hline $\mathrm{BL}$ & 133 & 37 & $28(20-35)$ & 45 & $34(26-42)$ & 56 & $42(34-50)$ \\
\hline $\mathrm{LL}$ & 42 & 6 & $14(3 \cdot 7-25)$ & 10 & $24(11-37)$ & 11 & $26(13-39)$ \\
\hline PN & 10 & 4 & $40(9 \cdot 6-70)$ & 2 & $20(0-45)$ & 5 & $50(19-81)$ \\
\hline Total & 396 & 96 & $24(20-28)$ & 116 & $29(25-34)$ & 141 & $36(31-40)$ \\
\hline
\end{tabular}

\footnotetext{
${ }^{\text {a }}$ Prevalence per 100 patients $+95 \%$ confidence interval.
} 
80 prevalence/100 patients

Motor loss Z Sensory loss Either

60

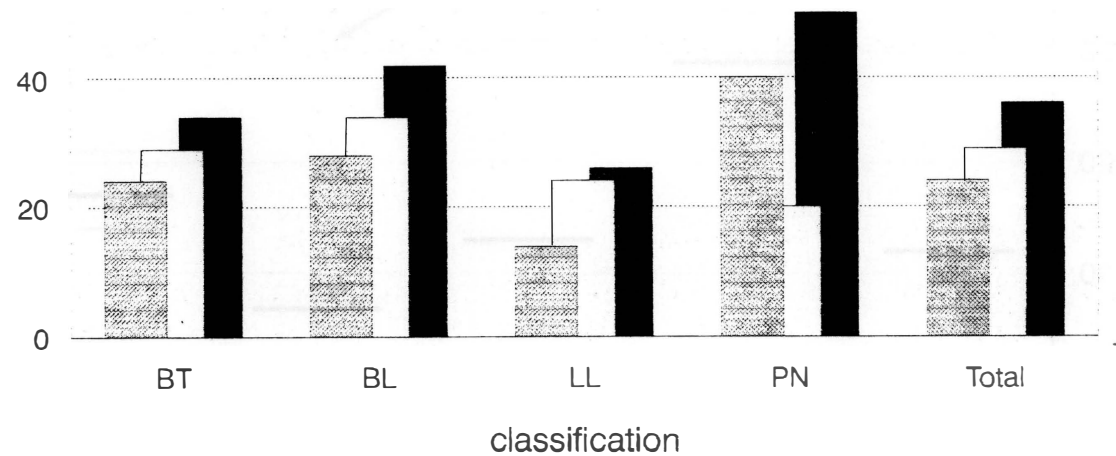

Figure 1. Prevalence of nerve function impairment at first registration $(n=387$; TT and BB patients have been omitted). Either $=$ motor and/or sensory impairment.

$(1 \cdot 4-3 \cdot 7), p=0 \cdot 0076)$. The rate-difference between BL and LL patients was not significant at the 5\% level (29 vs 13/100 PYAR, $p=0 \cdot 12)$. Sensory impairment occurred more frequently than motor impairment (rate ratio $1 \cdot 8(1 \cdot 2-2 \cdot 7), p=0 \cdot 0076$ ).

The prevalence of NFI for each separate nerve at the first examination is shown in Table 3. The posterior tibial nerve was the most frequent affected nerve, if only sensibility is considered ( $21 \mathrm{vs} 17 \%$ for the ulnar nerve). We did not assess the motor function of the posterior tibial nerve (intrinsic muscles of the foot) on a regular basis, but subjectively it seems that the secondary effects of posterior tibial motor weakness or paralysis, namely clawtoes and loss of foot arches, are also very common.

Table 2. Incidence rates of nerve function impairment in 335 previously untreated patients at Green Pastures Hospital. The mean follow-up time was 21 months

\begin{tabular}{|c|c|c|c|c|c|c|}
\hline \multirow[b]{2}{*}{ Classification } & \multicolumn{2}{|c|}{ Motor impairment } & \multicolumn{2}{|c|}{ Sensory impairment } & \multicolumn{2}{|c|}{ Either } \\
\hline & $\begin{array}{l}\text { Incident } \\
\text { cases }\end{array}$ & $\begin{array}{l}\text { Rates }^{\mathrm{a}} \\
(95 \% \mathrm{Cl})^{\mathrm{b}}\end{array}$ & $\begin{array}{l}\text { Incident } \\
\text { cases }\end{array}$ & $\begin{array}{c}\text { Rates } \\
(95 \% \mathrm{Cl})\end{array}$ & $\begin{array}{l}\text { Incident } \\
\text { cases }\end{array}$ & $\begin{array}{c}\text { Rates } \\
(95 \% \mathrm{Cl})\end{array}$ \\
\hline TT & 0 & & 0 & & 0 & \\
\hline BT & $14 / 170$ & $5 \cdot 1(3 \cdot 0-8 \cdot 7)$ & $28 / 182$ & $10(7 \cdot 1-1 \cdot 15)$ & $34 / 182$ & $12(8 \cdot 9-17)$ \\
\hline BB & $1 / 4^{c}$ & & $3 / 4^{\mathrm{c}}$ & & $3 / 4$ & \\
\hline BL & $14 / 106$ & $12(6 \cdot 9-20)$ & $27 / 106$ & $22(15-33)$ & $35 / 106$ & $29(21-40)$ \\
\hline LL & $4 / 31$ & $10(3 \cdot 8-27)$ & $2 / 31$ & $5 \cdot 1(1 \cdot 3-21)$ & $5 / 31$ & $13(5 \cdot 3-31)$ \\
\hline PN & $1 / 10$ & $6 \cdot 7(0 \cdot 9-47)$ & $1 / 10$ & $6 \cdot 7(0 \cdot 9-47)$ & $1 / 10$ & $6 \cdot 7(0 \cdot 9-47)$ \\
\hline Total & $34 / 335$ & $7 \cdot 5(5 \cdot 4-10)$ & $61 / 335$ & $13(10-17)$ & $78 / 335$ & $17(14-21)$ \\
\hline
\end{tabular}

\footnotetext{
${ }^{\mathrm{a}}$ Incidence rates per 100 person years at risk; ${ }^{\mathrm{b}} 95 \%$ confidence interval; ${ }^{\mathrm{c}}$ the numbers in the BB group were too small to calculate any meaningful rates.
} 


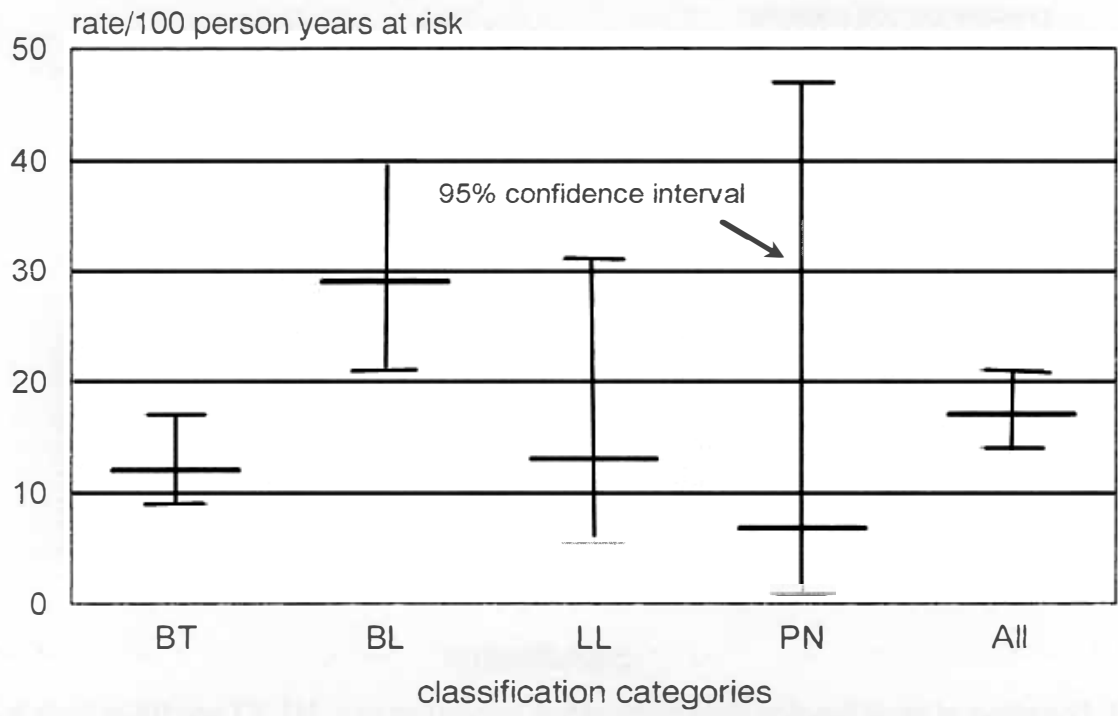

Figure 2. Incidence rates of nerve function impairment in 335 leprosy patients (PN, pure neuritic leprosy). TT cases (2) and BB cases (4) were omitted because no meaningful rates could be calculated.

In $3 / 792$ median nerves $(0 \cdot 4 \%)$ and $16 / 792$ ulnar nerves $(2 \cdot 0 \%)$ only motor function impairment could be detected (data not shown), and 7 median nerves $(0.9 \%)$ and 16 ulnar nerves $(2 \cdot 0 \%)$ had sensory impairment only.

Figure 3 illustrates the prevalence of impairment in individual nerves at registration.

TIME OF ONSET

Table 4 shows the distribution of patients with nerve function impairment according to the time of onset of the impairment. All together 152/396 (39\%) of patients required

Table 3. Prevalence at first registration of nerve function impairment in individual nerves. The numbers in the table refer to patients rather than nerves

\begin{tabular}{|c|c|c|c|c|c|c|c|c|}
\hline \multirow[b]{2}{*}{ Nerve } & \multicolumn{4}{|c|}{ Motor impairment } & \multicolumn{4}{|c|}{ Sensory impairment } \\
\hline & $\begin{array}{l}\text { One side } \\
\text { only }(\%)\end{array}$ & $\begin{array}{l}\text { Both } \\
(\%)\end{array}$ & Total & $\begin{array}{l}\text { Prevalence } \\
(\%)^{\mathrm{a}}\end{array}$ & $\begin{array}{l}\text { One side } \\
\text { only }(\%)\end{array}$ & $\begin{array}{l}\text { Both } \\
(\%)\end{array}$ & Total & $\begin{array}{c}\text { Prevalence } \\
(\%)\end{array}$ \\
\hline Facial & $11(2 \cdot 8)$ & $11(2 \cdot 8)$ & 22 & $5 \cdot 6(3 \cdot 3-7 \cdot 8)$ & & & & \\
\hline Ulnar & $54(14)$ & $27(6 \cdot 8)$ & 81 & $20(16-24)$ & $39(9 \cdot 8)$ & $30(7 \cdot 6)$ & 69 & $17(14-21)$ \\
\hline Median & $7(1 \cdot 8)$ & $8(2)$ & 15 & $3.8(1.9-5 \cdot 7)$ & $22(5 \cdot 6)$ & $13(3 \cdot 3)$ & 35 & $8 \cdot 8(6 \cdot 0-12)$ \\
\hline Radial & $4(1 \cdot 0)$ & 0 & 4 & $1.0(0.03-2)$ & & & & \\
\hline Lat. Popliteal & $16(4)$ & $3(0 \cdot 8)$ & 19 & $4 \cdot 8(2 \cdot 7-6 \cdot 9)$ & & & & \\
\hline Posterior Tibial & & & & & $35(8 \cdot 8)$ & $50(13)$ & 85 & $21(17-26)$ \\
\hline
\end{tabular}

Data on the sensory function of the lateral popliteal nerve and the motor function of the posterior tibial nerve were not collected. ${ }^{a}$ Prevalence per 100 patients $+95 \%$ confidence interval. 
Table 4. Number of patients in different 'onset of nerve function impairment' categories

\begin{tabular}{|c|c|c|}
\hline Category of NFI & Number & $\%$ \\
\hline None & 181 & 46 \\
\hline $\mathrm{Old}^{\mathrm{a}}$ & 63 & 16 \\
\hline Recent $^{\mathrm{b}}$ & 74 & 19 \\
\hline Acquired $^{c}$ & 78 & 20 \\
\hline Total & 396 & 100 \\
\hline
\end{tabular}

\footnotetext{
${ }^{\text {a }}$ Onset $>6$ months ago at the time of registration; ${ }^{b}$ onset $<6$ months ago at the time of registration; ${ }^{c}$ nerve function impairment detected during or after treatment that was not present at the time of registration.
}

steroid treatment for nerve function impairment during or after their antileprosy treatment.

\section{RISK FACTORS}

Among the patients developing new NFI after the start of antileprosy treatment, no significant difference in risk was found between those on MDT and those on DDS. Table 5 summarizes the significance of individual risk factors in relation to the incidence of nerve impairment. There was no association between incidence of NFI and age of registration, sex, PGL-1 antibody titre or bacteriological index of the patient.

Table 5. Risk factors for nerve function impairment occurring after the start of antileprosy treatment among 335 new patients in Green Pastures Hospital

\begin{tabular}{|c|c|c|c|}
\hline Risk factor & $\begin{array}{l}\text { Category of } \\
\text { patients }\end{array}$ & $\begin{array}{l}\text { Rate ratio } \\
(95 \% \mathrm{Cl})^{\mathrm{b}}\end{array}$ & $p$-value \\
\hline Sex & all & $1 \cdot 1(0 \cdot 63-1 \cdot 8)$ & $0 \cdot 79$ \\
\hline Treatment (MDT vs. DDS) $^{\mathrm{c}}$ & all & $0 \cdot 56(0 \cdot 27-1 \cdot 1)$ & $0 \cdot 11$ \\
\hline $\begin{array}{l}\text { Extent of clinical disease: } \\
\quad>10 \text { skin lesions }\end{array}$ & all & $3 \cdot 2(1 \cdot 4-7 \cdot 1)^{\mathrm{d}}$ & 0.0044 \\
\hline$>3$ nerves enlarged & all & $3 \cdot 3(1 \cdot 4-8 \cdot 0)^{\mathrm{d}}$ & 0.0082 \\
\hline$>2$ body areas involved & $\begin{array}{l}\text { all } \\
\mathrm{B}^{\mathrm{e}}\end{array}$ & $\begin{array}{l}5 \cdot 0(1 \cdot 5-17) \\
6 \cdot 6(1.6-29)\end{array}$ & $\begin{array}{l}0.0091 \\
0.011\end{array}$ \\
\hline bacteriological index & all & $1 \cdot 6(0 \cdot 85-2 \cdot 9)$ & $0 \cdot 11$ \\
\hline PGL-1 & $\mathrm{B}^{\mathrm{e}}$ & $0.92(0.51-1.7)$ & $0 \cdot 77$ \\
\hline
\end{tabular}

\footnotetext{
${ }^{\text {a }}$ Rate ratio adjusted for the simultaneous influence of age, sex, treatment, bacteriological index, phenolic glycolipid-1 antibody (PGL-1) titre and body area count; ${ }^{b} 95 \%$ confidence interval; ${ }^{\mathrm{c}}$ multidrug therapy versus dapsone monotherapy; ${ }^{\mathrm{d}}$ rate ratio adjusted for the simultaneous influence of age, sex, treatment, bacteriological index, and PGL-1 titre; ${ }^{\mathrm{e}}$ borderline patients; ${ }^{\mathrm{f}}$ PGL-1 titre $(>0 \cdot 199=$ positive $)$.
} 


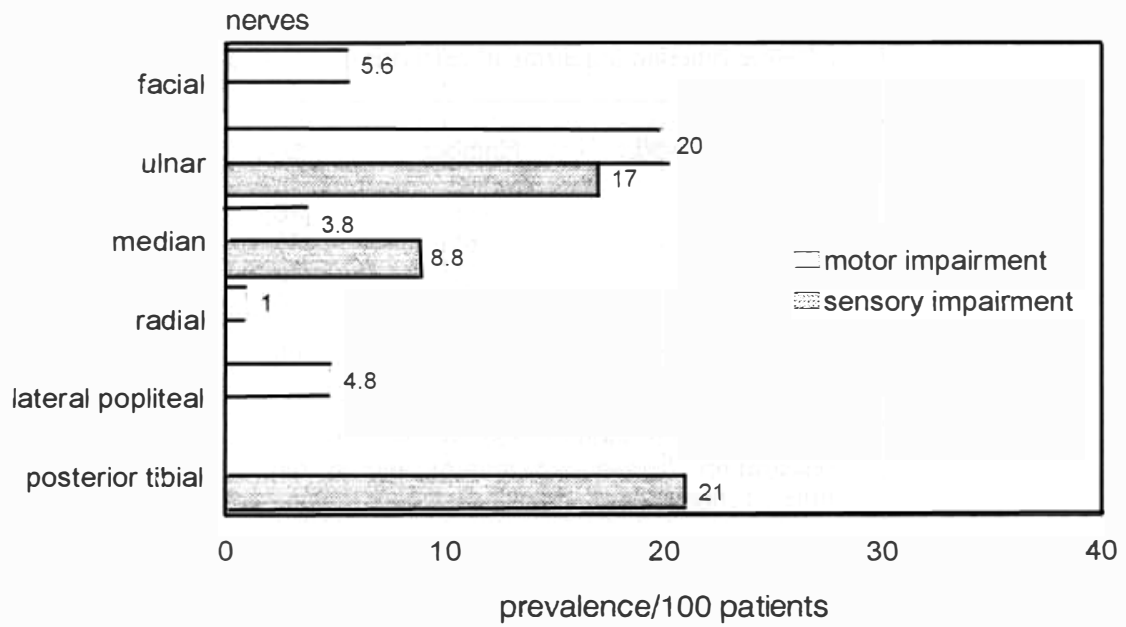

Figure 3. Prevalence of impairment at first registration in individual nerves in 396 new leprosy patients in Green Pastures Hospital. Data on the sensory function of the lateral popliteal nerve and the motor function of the posterior tibial nerve were not collected.

Unfortunately, data on pregnancy and lactation were not systematically recorded and therefore valid analysis of these risk factors was not possible.

The extent of clinical disease expressed as the number of body areas (out of 9) with primary or secondary signs of leprosy, ${ }^{31}$ was a highly significant risk factor for developing neural impairment. The rate ratio of NFI for patients with $>2$ body areas involved in the disease ('extensive disease') compared to those with 2 or less was $5 \cdot 0(1 \cdot 5-$ $17, p=0 \cdot 0091$ ), i.e. the risk of developing impairment for patients with $>2$ body areas involved was 5 times higher than the risk for patients with only 1 or 2 body areas involved. Using skin lesion counts and taking 10 lesions as the cut-off point, the rate ratio was $3 \cdot 2(1 \cdot 4-7 \cdot 1, p=0 \cdot 0044)$ for patients with 'extensive' disease. These rate ratios are illustrated in Figure 4.

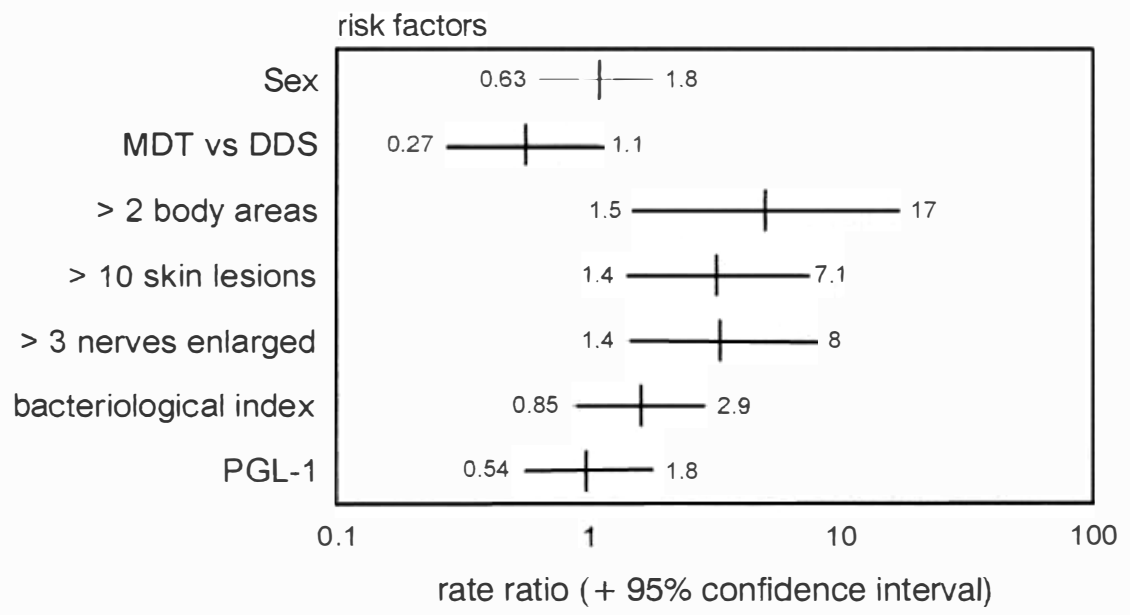

Figure 4. Risk factors for nerve function impairment in 335 new leprosy patients. MDT, multi-drug therapy; DDS, dapsone monotherapy; PGL-1, phenolic glycolipid-1 antibody positive. 


\section{Discussion}

The peripheral neuropathy of leprosy has been neurologically classified by several investigators as a 'mononeuritis multiplex', ${ }^{36-38}$ because there is a widespread, bilateral, but not homogeneous or systemic neuropathy involving both the sensory and motor fibre systems. A part of the nerve may show extensive destruction, while a nearby section of the same nerve may have a histopathologically normal appearance. ${ }^{19,20}$ The neuropathy begins very early in the disease process and progresses to a considerable extent with destruction of Schwann cells and segmental demyelination, as well as extensive regeneration and re-myelination, even before the immune system becomes involved. ${ }^{15,16,39}$ Once the immune response is initiated, inflammatory processes with destruction through granuloma formation, intraneural oedema and ischaemia dominate the pathophysiological picture. ${ }^{1,22,26}$ It is clear from the available pathological evidence that extensive neuropathy is already present before the patient notices any signs and symptoms of nerve function impairment. The NFI discussed below is therefore only the 'tip of the iceberg' of the peripheral neuropathy of leprosy. Concerning our data in this study, it should be born in mind that our nerve function assessment instruments were crude, particularly for sensibility testing, and that, therefore, the true prevalence and incidence in these patients is likely to be higher than reported here.

Table 6. Comparison of publications on the prevalence of sensory nerve function impairment in leprosy

\begin{tabular}{|c|c|c|c|c|c|c|c|c|c|}
\hline \multirow{2}{*}{$\begin{array}{l}\text { Author } \\
\text { (new or treated } \\
\text { patients, or mixed) }\end{array}$} & \multirow[b]{2}{*}{ Type of patients } & \multirow{2}{*}{$\begin{array}{l}\text { Testing } \\
\text { methods }\end{array}$} & \multirow{2}{*}{$\begin{array}{l}\text { Nerves } \\
\text { examined }\end{array}$} & \multicolumn{6}{|c|}{$\begin{array}{l}\text { Prevalence of nerve function } \\
\text { impairment by classification (\%) }\end{array}$} \\
\hline & & & & TT & BT & BB & BL & LL & Overall \\
\hline $\begin{array}{l}\text { Brunel et al. }{ }^{62} \\
\text { (treated) }\end{array}$ & $\begin{array}{l}25 \text { Tuberculoid } \\
18 \text { Borderline } \\
57 \text { Lepromatous }\end{array}$ & $2 \mathrm{PD}^{\mathrm{a}}$ & $\begin{array}{l}\text { all } \\
\text { ulnar } \\
\text { median } \\
\text { ulnar }+ \text { median }\end{array}$ & 20 & & 5 & & 65 & $\begin{array}{r}54 \\
21 \\
6 \\
71\end{array}$ \\
\hline $\begin{array}{l}\text { Dorairaj et } a l .{ }^{42} \\
\text { (mixed) }\end{array}$ & $\begin{array}{l}100 \text { in-patients (IP) } \\
100 \text { village patients (VP) }\end{array}$ & $\operatorname{TST}(\mathrm{mf})^{\mathrm{b}}$ & post.tib. & & & & & & $\begin{array}{l}\text { IP } 78 \\
\text { VP } 63\end{array}$ \\
\hline $\begin{array}{l}\text { Becx-Bleumink \& } \\
\text { Berhe }^{10} \text { (treated) }\end{array}$ & $\begin{array}{l}161 \text { field patients with recent } \\
(<6 \text { months) NFI }\end{array}$ & TST (bp) & $\begin{array}{l}\text { SNFI }^{\mathrm{c}} \\
\text { ulnar } \\
\text { median } \\
\text { post.tib. }\end{array}$ & & & & & & $\begin{array}{l}49 \\
44 \\
36 \\
68\end{array}$ \\
\hline $\begin{array}{l}\text { Bell-Krotoski } \\
\text { (treated) }\end{array}$ & $\begin{array}{l}221 \text { community-based } \\
\text { hospital outpatients (CBP) }\end{array}$ & TST (mf) & $\mathrm{CBP}(\mathrm{S})$ & 55 & 50 & 50 & 75 & 75 & 67 \\
\hline $\begin{array}{l}\text { Brown et al. }{ }^{41} \\
\text { (treated) }\end{array}$ & $\begin{array}{l}35 \text { hospital outpatients } \\
3 \mathrm{TT}, 13 \mathrm{BT}, 2 \mathrm{BB} \text {, } \\
11 \mathrm{BL}, 6 \mathrm{LL}\end{array}$ & $\begin{array}{l}\text { TST (mf) } \\
\text { SNC }^{c}\end{array}$ & $\begin{array}{l}\text { ulnar, TST } \\
\text { SNC } \\
\text { median, TST } \\
\text { SNC } \\
\text { radial, TST } \\
\text { SNC }\end{array}$ & & & & & & $\begin{array}{l}29 \\
54 \\
13 \\
29 \\
29 \\
37\end{array}$ \\
\hline $\begin{array}{l}\text { van Brakel \& Khawas } \\
\text { (new) }\end{array}$ & $\begin{array}{l}\text { Hospital outpatients (new) } \\
2 \mathrm{TT}, 202 \mathrm{BT}, 7 \mathrm{BB} \text {, } \\
133 \mathrm{BL}, 42 \mathrm{LL}, 10 \mathrm{PN}\end{array}$ & $\mathrm{TST}(\mathrm{mf})$ & $\begin{array}{l}\text { SNFI } \\
\text { ulnar(S) } \\
\text { median(S) } \\
\text { post.tib (S) }\end{array}$ & 0 & 29 & 0 & 34 & 24 & $\begin{array}{l}29 \\
17 \\
8 \cdot 8 \\
21\end{array}$ \\
\hline
\end{tabular}

a $2 \mathrm{PD}, 2$-point discrimination (static); ${ }^{\mathrm{b}} \mathrm{mf}$, monofilament: 1 or more graded nylon monofilaments; bp, ballpoint pen; ${ }^{\mathrm{c}}$ SNFI, sensory nerve function impairment; ${ }^{\mathrm{d}} \mathrm{SNC}$, sensory nerve conduction testing (including velocity, amplitude and latency). 
Table 7. Comparison of publications on prevalence of motor nerve function impairment in leprosy

\begin{tabular}{|c|c|c|c|c|c|c|c|c|c|}
\hline \multirow{2}{*}{$\begin{array}{l}\text { Author } \\
\text { (new or old } \\
\text { patients, or mixed) }\end{array}$} & \multirow[b]{2}{*}{ Type of patients } & \multirow{2}{*}{$\begin{array}{l}\text { Testing } \\
\text { methods }\end{array}$} & \multirow{2}{*}{$\begin{array}{l}\text { Nerves } \\
\text { examined }\end{array}$} & \multicolumn{6}{|c|}{$\begin{array}{l}\text { Prevalence of nerve function } \\
\text { impairment by classification (\%) }\end{array}$} \\
\hline & & & & TT & BT & BB & $\mathrm{BL}$ & LL & Overall \\
\hline $\begin{array}{l}\text { Magora et al. } \\
\text { (new?) }\end{array}$ & $\begin{array}{l}20 \text { Indeterminate } \\
8 \text { Tuberculoid } \\
\text { 8 Dimorphous } \\
67 \text { Lepromatous }\end{array}$ & $\mathrm{MCV}^{\mathrm{a}}$ & $\begin{array}{l}\text { ulnar, } 206^{\mathrm{b}} \\
\text { median, } 77 \\
\text { radial, } 46 \\
\text { lat.pop, } 108\end{array}$ & & & & & & $\begin{array}{l}26 \\
13 \\
6 \cdot 5 \\
16\end{array}$ \\
\hline $\begin{array}{l}\text { Becz-Bleumink \& } \\
\text { Berhe }^{10} \text { (treated) }\end{array}$ & $\begin{array}{l}161 \text { field patients with recent } \\
(<6 \text { months NFI) }\end{array}$ & $\operatorname{VMT}(s)^{c}$ & $\begin{array}{l}\text { MNFI } \\
\text { facial } \\
\text { ulnar } \\
\text { median } \\
\text { lat.pop }\end{array}$ & & & & & & $\begin{array}{l}23 \\
29 \\
39 \\
15 \\
11\end{array}$ \\
\hline $\begin{array}{l}\text { Bell-Krotoski }{ }^{6} \\
\text { (treated) }\end{array}$ & $\begin{array}{l}221 \text { community-based } \\
\text { hospital outpatients (CBP) }\end{array}$ & VMT (1) & CBP & 55 & 60 & 65 & 70 & 70 & 65 \\
\hline $\begin{array}{l}\text { Brown et al. }{ }^{41} \\
\text { (treated) }\end{array}$ & $\begin{array}{l}35 \text { hospital outpatients } \\
3 \mathrm{TT}, 13 \mathrm{BT}, 2 \mathrm{BB} \text {, } \\
11 \mathrm{BL}, 6 \mathrm{LL}\end{array}$ & $\begin{array}{l}\text { VMT (l) } \\
\text { MNC }^{d}\end{array}$ & $\begin{array}{l}\text { ulnar, VMT } \\
\text { MNC } \\
\text { median, VMT } \\
\text { MNC } \\
\text { radial, VMT }\end{array}$ & & & & & & $\begin{array}{l}30 \\
37 \\
13 \\
20 \\
10\end{array}$ \\
\hline $\begin{array}{l}\text { van Brakel \& Khawas } \\
\text { (new) }\end{array}$ & $\begin{array}{l}\text { Hospital patients (new) } \\
2 \mathrm{TT}, 202 \mathrm{BT}, 7 \mathrm{BB} \text {, } \\
133 \mathrm{BL}, 42 \mathrm{LL}, 10 \mathrm{PN}\end{array}$ & VMT (l) & $\begin{array}{l}\text { MNFI } \\
\text { facial } \\
\text { ulnar } \\
\text { median } \\
\text { radial } \\
\text { lat.pop }\end{array}$ & 0 & 24 & 0 & 28 & 14 & $\begin{array}{c}24 \\
5 \cdot 6 \\
20 \\
3 \cdot 8 \\
1 \cdot 0 \\
4 \cdot 8\end{array}$ \\
\hline
\end{tabular}

${ }^{\mathrm{a}} \mathrm{MCV}$, motor nerve conduction velocity testing; ${ }^{\mathrm{b}}$ the numbers refer to the number of nerves tested; ${ }^{\mathrm{c}} 1$, 'long' VMT, using 0-5 MRC scale; s, 'short' VMT, using only the categories 'strong', 'weak' and 'paralysed; ${ }^{\mathrm{d}} \mathrm{MNC}$, motor nerve conduction testing (including velocity, amplitude and latency).

\section{THE PREVALENCE AND INCIDENCE OF NERVE FUNCTION IMPAIRMENT}

The published studies of an epidemiological nature on the occurrence of NFI in leprosy that deal with bigger numbers of patients are summarized in Tables 6 and 7. There is considerable variance between the results due to differences in methods of testing, criteria for selection of patients (often not mentioned), etc.

The prevalence of ulnar, median, lateral popliteal and posterior tibial impairment found by Becx-Bleumink $\&$ Berhe $^{10}$ was understandably higher than in the present study since they report on a select group of treated patients with nerve function impairment. Overall motor impairment prevalence in the former study was $23 \%$ vs $24 \%$ in ours. These similar results may be explained by the fact that our study used a more detailed VMT, detecting more motor impairment than the short field VMT used in the Ethiopian study. Srinivasan et al. ${ }^{40}$ found $46.7 \%$ motor impairment in 373 ulnar nerves.

Brown et al., testing with graded nylon monofilaments, reported a prevalence of sensory impairment of $29 \%$ for ulnar and $13 \%$ for median nerves. ${ }^{41}$ This is appreciably more than in our study, probably due to the fact that Brown et al. used graded monofilaments, which are much more sensitive than the single filament we used. Dorairaj et al. found $63 \%$ posterior tibial impairment among village patients, ${ }^{42}$ which is very similar to the $68 \%$ found by Becx-Bleumink.

The incidence of neural impairment was higher in BL patients than in BT patients. This may be due to the increased risk of reversal reactions among BL patients that has 
been observed in Ethiopian patients and also in ours. ${ }^{10,43} \mathrm{~W}$ e are not aware of any other studies reporting the incidence rates of neural impairment, so no direct comparisons could be made.

\section{RISK FACTORS}

One of the most significant findings of this study is that extensive clinical disease, expressed as 'number of body areas involved' or as a count of skin or nerve lesions, carries a much higher risk of developing nerve function impairment than limited disease. For NFI occurring after the start of antileprosy treatment this risk was increased up to 5 times. This means that new patients with extensive disease ( $>2 / 9$ body areas involved, and/or $>10$ skin leasions and/or $>3$ nerves enlarged) should be given appropriate health education, encouraging them to come back for examination immediately should any signs or symptoms of NFI or neuritis occur. Their nerve function should be carefully monitored at every clinic visit.

\section{NERVE FUNCTION ASSESSMENT}

Our ability to detect peripheral neuropathy obviously depends on the sensitivity of the instruments used during the NFA. In Nepal many field staff believed until recently that motor function was more important than sensibility, so if any assessment was carried out, it was only a crude field VMT. The importance of sensibility was well-illustrated by Moberg $^{44}$ when he called touch sensibility or 'tactile gnosis' the 'eyes of the hands'. Without it the hands are 'blind' and therefore severely disabled, and prone to trophic ulceration. The current results underline the importance of the testing of sensibility as the incidence of sensory impairment was almost twice as high as the incidence of motor impairment. Sensory testing in the field is usually done with the 'ballpen test', as recommended by Jean Watson. ${ }^{45}$ This test and the field VMT certainly brought a great improvement to many field programmes where no NFA was done at all, but these tests as well as our 10-g and 75-g monofilaments are not sensitive enough to detect early NFI.

There are 3 areas which are of particular importance in the assessment of nerve function in leprosy:

\section{Early detection of NFI}

This is based on the assumption that early detection will lead to improved treatment prognosis. It has been shown that motor and sensory nerve conduction velocity measurements are able to pick up NFI before it becomes clinically evident. ${ }^{7,46}$ Brown et al. found up to twice as much neural impairment with nerve conduction testing as with manual tests of sensibility and motor function. ${ }^{41}$ Other modern advanced techniques that have been reported to be sensitive in diagnosing NFI in leprosy include radioisotopic scintillography in a gamma camera, ${ }^{3}$ vibrometry, ${ }^{47}$ and the use of a laser Doppler flow meter. ${ }^{48}$ A range of simple but useful neurological tests is available that could be used even under field conditions. ${ }^{49}$

Many of our patients who had 'normal' sensibility when measured with the previously used 10-g monofilament already had advanced impairment of touch sensibility when tested with the graded Semmes-Weinstein monofilaments, where the 
force for 'normal' is $200 \mathrm{mg}$ (data not shown). The use of graded nylon monofilaments has been found to be a sensitive and repeatable method to detect early nerve damage and to monitor the response of NFI to treatment. ${ }^{49-52}$ It would greatly facilitate comparison of study results if the filaments and testing technique used would be standardized. A detailed description of the 'state of the art' of this testing method was given by BellKrotoski. $^{53}$

Although epidemiological evidence is lacking it seems reasonable, on the basis of the histopathological evidence, ${ }^{54}$ to believe that autonomic function and temperature discrimination, mediated by small, unmyelinated fibres, may be affected first. Reliable and repeatable testing of these modalities remains difficult, but has become possible with electronic instruments. ${ }^{48,55}$ These instruments could also be of help for the so important testing of validity and reliability of NFA instruments. ${ }^{56}$

\section{Protective sensibility}

Although detection of early NFI is very important from the point of view of treatment/ prevention, it is of great practical importance to know whether a patient has residual protective sensibility in hands or feet. Discussion of what constitutes protective sensibility is beyond the scope of this paper. The level of residual protective sensibility, expressed as touch sensibility thresholds, has been found to be $2 \mathrm{~g}$ in the hand, ${ }^{57}$ and about $10 \mathrm{~g}$ in the foot. ${ }^{47,58}$

\section{The patient's point of view}

From a patient's point of view there are three conditions affecting the quality of life that are of major importance. The presence or absence of uncomfortable symptoms, like paraesthesia and shooting pains, physical deformities, and the (dis-)ability to function normally. If such adverse conditions can be cured or prevented, or at least minimized, the patient will be satisfied with his treatment. Therefore, the prevention of impairments and disabilities should be a priority of treatment. Effective antibacterial treatment is essential, but several investigators ${ }^{10,59-61}$ have suggested that powerful bactericidal therapy might increase the risk of severe reactions and NFI. The current study revealed no differences in the risk of developing NFI between patients on MDT and those on dapsone monotherapy. However, caution is necessary. New and even stronger antibacterial drug combinations, which do not contain clofazimine, should be carefully monitored for incidence of NFI compared with other standard regimens. More data on the epidemiology of nerve function impairment and reactions in leprosy under current treatment regimens are therefore urgently needed.

The data in this paper refer to a self-selected group of hospital outpatients who are likely to be at higher risk of NFI than the whole leprosy 'patient population' which they are a part of. The prevalence and incidence figures can, therefore, only be generalized to referral centres and not to field programmes. The risk indicators should be valid even under field conditions, although confirmation of this is needed. Whatever the true rates in the population, it is evident that neural impairment is a frequent complication of leprosy, even after effective antileprosy treatment has been initiated. Regular assessment of nerve function should be a regular part of the management of every leprosy patient, particularly of those identified to be at increased risk. 


\section{Conclusions}

With the nerve function assessment instruments used in this study about $33 \%$ of our patients were found to have sensory and/or motor impairment at first examination.

An additional $78(20 \%)$ developed severe NFI during or after their antileprosy treatment in a mean follow-up period of 21 -months. NFI is thus not an infrequent complication affecting patients on regular antileprosy treatment.

Risk of developing nerve function impairment was increased in patients who had more extensive clinical disease ( $>2 / 9$ body areas involved or $>10$ skin lesions).

Further epidemiological studies on peripheral neuropathy in leprosy, validation of NFA instruments, and trials and improved protocols for the treatment and prevention of NFI are urgently needed.

\section{Acknowledgments}

The authors wish to thank the anonymous referee for detailed and very helpful comments. Professor Paul E. M. Fine gave helpful comments concerning the epidemiological indicators used in this study. We thank Dr Yolanda van der Graaf for constructive criticism on some of the methods used. We are indebted to the staff of the physiotherapy department at GPH who spend much of their time performing detailed functional assessments, on which this study was based. The work at GPH is dedicated to the service and glory of God.

\section{References}

${ }^{1}$ Ridley DS, Job CK. The pathology of leprosy. In: Hastings RC (ed) Leprosy. Edinburgh: Churchill Livingstone, 1985.

2 Antia NH. Some newer approaches to the study of nerve damage in leprosy. In: Proceedings, XII International Leprosy Congress. New Delhi, 1984: 435-8.

${ }^{3}$ Charosky CB, Gatti JC, Cardama JE. Neuropathies in Hansen's disease. Int J Lepr, 1983; 51: 576-86.

${ }^{4}$ Naafs B. Leprosy Reactions. Quad Coop San, 1992; 12: 67-72.

${ }^{5}$ McLeod JG. Peripheral nerve lesions. Med Int, 1992; 5 (18): 4191-7.

6 Bell-Krotoski JA. A study of peripheral nerve involvement underlying physical disability of the hand in a Hansen's disease population. J. Hand Ther, 1992; 5: 133-42.

7 McLeod JG, Hargrave JC, Walsh JC, Booth GC, Gye RS, Barron A. Nerve conduction studies in leprosy. Int J Lepr, 1975; 43: 21-31.

8 Duncan ME, Pearson JMH. Neuritis in pregnancy and lactation. Int J Lepr, 1982; 50: 31-8.

9 Becx-Bleumink M, Berhe D, 'T Mannetje W. The management of nerve damage in the leprosy control services. Lepr Rev, 1990; 61: 1-11.

10 Becx-Bleumink M, Berhe D. Occurrence of reactions, their diagnosis and management in leprosy patients treated with multidrug therapy; experience in the Leprosy Control Program of the All Africa Leprosy and Rehabilitation Training Centre (ALERT) in Ethiopia. Int J Lepr, 1992; 60: 173-84.

11 Weddell G, Jamison D, Palmer E. Recent investigations into the sensory and neurohistological changes in leprosy. In: Leprosy in Theory and Practice. Cochrane RG (ed). Bristol: John Wright \& Sons, Ltd, 1959: 96113.

12 Boddingius J. Ultra-structural changes in blood vessels of peripheral nerves in leprosy patients (tuberculoid and borderline-tuberculoid). Acta Neuropath, 1976; 35: 159-81.

13 Boddingius J. Ultra-structural changes in blood vessels of peripheral nerves in leprosy patients (Borderline, Borderline-lepromatous, Lepromatous). Acta Neuropath, 1977; 40: 21-39.

14 Boddingius J. Ultra-structural and histophysiological studies on the blood nerve barrier and perineural barrier in leprosy neuropathy. Acta Neuropath, 1984; 64: 282-96. 
15 Anita NH, Mehta LN, Shetty VP, Irani PF. Clinical, electrophysiological, quantitative, histologic and ultrastructural studies of the index branch of the radial cutaneous nerve in leprosy. I. Preliminary report. Int J Lepr, 1975; 43: 106-13.

16 Shetty VP, Mehta LN, Irani PF, Antia NH. Study of the evolution of nerve damage in leprosy: part Ilesions of the index branch of the radial cutaneous nerve in early leprosy. Lepr Ind, 1980; 52: 5-18.

17 Shetty VP, Vidyasagar PB, Antia NH. Study of the evolution of nerve damage in leprosy: part III-sciatic nerve lesions in mice inoculated with M. le prae with nerve conduction velocity correlates. Le pr Ind, 1980; 52: 26-47.

18 Vidyasagar PB, Damle PS, Antia NH. A study of the sciatic nerve compound action potential in vitro in normal and M. leprae infected mice. Le pr Ind, 1981; 53: 537-54.

19 Dastur DK, Pandya SS, Antia NH. Nerves in the arm in leprosy. Int J Lepr, 1970; 38: 30.

20 Dastur DK. Pathology and pathogenesis of predilective sites of nerve damage in leprous neuritis. Nerves in the arm and the face. Neurosurg Rev, 1983; 6: 139-52.

${ }^{21}$ Chopra JS, Kaur S, Murthy JMK, Radhakrishnan K, Kumar B. Clinical, electrophysiological and teased fibre study of peripheral nerves in leprosy. Ind J Med Res, 1983; 77: 713-21.

22 Job CK. Nerve damage in leprosy. Int J Lepr, 1989; 57: 532-9.

${ }^{23}$ Sabin TD, Ebner JD. Patterns of sensory loss in lepromatous leprosy. Int J Lepr, 1969; 37: 239-48.

24 Sabin TD. Temperature-linked sensory loss. A unique pattern in leprosy. Arch Neurol, 1969; 20: $257-62$.

${ }^{25}$ Swift TR. Peripheral nerve involvement in leprosy: quantitative histologic aspects. Acta Neuropath, 1974; 29: $1-8$.

26 Pearson JMH, Ross WF. Nerve involvement in leprosy - pathology, differential diagnosis and principles of management. Lepr Rev, 1975; 46: 199-212.

27 Naafs B, Pearson JMH, Baar AJM. A follow-up study of nerve lesions in leprosy during and after reaction using motor nerve conduction velocity. Int J Lepr, 1976; 44: 188-97.

28 Notermans NC, Wokke JHJ, Jennekens FGI. Clinical work-up of the patient with a polyneuropathy. In: de Jong JMBV (ed), Handbook of Clinical Neurology. Elseviers Scientific Publishers B.V., 1991.

29 A Guide to Leprosy Control. 2nd edition. WHO, 1988.

30 World Health Organisation. International classification of impairments, disabilities and handicaps. Geneva: WHO, 1980.

31 van Brakel WH, de Soldenhoff R, McDougall AC. The allocation of leprosy patients into paucibacillary and multibacillary groups for multidrug therapy, taking into account the number of body areas affected by skin, or skin and nerve lesions. Lepr Rev, 1992; 63: 231-45.

32 Medical Research Council War Memorandum. Aids to the investigation of peripheral nerve injuries. (Memo no. 7), 2nd ed, London: HMSO, 1962.

33 Brandsma W. Basic nerve function assessment in leprosy patients. Lepr Rev, 1981; 52: 161-70.

34 Armitage P, Berry G. Statistical Methods in Medical Research. 2nd ed. Oxford: Blackwell Scientific Publications, 1987: 121-4.

35 Dean AG, Dean JA, Dicker RC. Epi Info, Version 5: a word processing, database, and statistics program for epidemiology on microcomputers. USD, Inc., Stone Mountain, Georgia, 1990.

36 Verghese M, Ittimani KV, Satyanaran KR, Mathai R, Bhakthaviriam C. A study of the conduction velocity of the motor fibres of the ulnar and median nerves in leprosy. Int $J$ Le pr, 1970; 38: 271.

37 Tzourio C, Henry P, Boucher P, Parent M, Millan J, Métral S. Lèpre lépromateuse: arguments clinique et électrophysiologiques en faveur d'une multinévrite axonale. Act Lepr, 1989; 7 (1): 51-6.

38 Jennekens FGI, Jennekens-Schinkel. A. Neurological examination of patients suffering from leprosy: is it worthwhile? Lepr Rev, 1992; 63: 269-76.

39 Antia NH. Leprosy-a disease of the Schwann cell. Lepr Ind, 1982; 54: 599-604.

40 Srinivasan H, Namasivayam PR. Does entrapment neuropathy contribute to nerve damage in leprosy? Ind $J$ Med Res, 1971; 59: 1385-91.

41 Brown RB, Kovindha A, Wathanadilokkokol U, Piefer A, Smith T, Kraft GH. Clinical assessment of early leprous neuropathy with electrophysiological correlation. Paper presented at the 14th International Leprosy Congress, Orlando, Florida, 1993. (Abstract no. 35 in 'Abstracts').

42 Dorairaj A, Reddy R, Jesudasan K. An evaluation of the Semmes-Weinstein 6.10 monofilament compared with 6 nylon in leprosy patients. Ind J Lepr, 1988; 60: 413-7.

43 van Brakel WH, Lucas SB, Khawas IB. Reactions in leprosy: an epidemiological study of 386 patients in West Nepal. Lepr Rev, 1994; 65, 190-203

44 Moberg E. Objective methods of determining functional value of sensibility in the hand. J Bone Jt Surg (UK), 1958; 40: 454-66.

45 Watson JM. Essential action to minimise disability in leprosy patients. The Leprosy Mission International. Stanley L. Hunt (Printers) Ltd, 1988.

${ }^{46}$ Hackett ER, Shipley DE, Livengood R. Motor nerve conduction velocity studies of the ulnar nerve in patients with leprosy. Int J Lepr, 1968; 36: 282.

47 Hammond CJ, Klenerman P. Protective sensation in the foot in leprosy. Lepr Rev, 1988; 59: 347-54. 
48 Abbot NC, Beck JS, Samson PD, Butlin CR, Brown RA, Forster A, Grange JM, Cree IA. Impairment of fingertip vasomotor reflexes in leprosy patients and apparently healthy contacts. Int J Lepr, 1991; 59: 53747.

49 Pearson JMH. The evaluation of nerve damage in leprosy. Lepr Rev, 1982; 53: 119-30.

50 Mehta LN, Shetty VP, Antia NH, Irani PF. Quantitative, histologic and ultrastructural studies of the index branch of the radial cutaneous nerve in leprosy and it's correlation with electrophysiologicic study. Int $J$ Lepr, 1975; 43: 256-64.

51 Naafs B, Dagne T. Sensory testing: a sensitive method in the follow-up of nerve involvement. Int J Lepr, 1977; 45: 364-8.

52 Bell-Krotoski JA, Tomancik E. The repeatability of testing with Semmes-Weinstein Monofilaments. $J$ Hand Surg, 1987; 12A: 155-61.

53 Bell-Krotoski JA. Light touch-deep pressure testing using Semmes-Weinstein monofilaments. In: Rehabilitation of the hand, 3rd ed. Hunter et al. (eds) C. V. Mosby Co., 1989; 585-93.

54 Antia NH, Shetty VP, Mehta LN. Study of the evolution of nerve damage in leprosy: part IV-an assessment. Lepr Ind, 1980; 52: 48-52.

55 Elderson A, Gerritsen van der Hoop R, Haanstra W, Neijt JP, Gispen WH, Jennekens FGI. Vibration perception and thermoperception as quantative measurements in the monitoring of cisplatin induced neurotoxicity. J Neurol Sci, 1989; 93: 167-74.

56 Ewing Fess E. The need for reliability and validity testing in hand assessment instruments. $J$ Hand Surg, 1986; 11A: 621-3.

57 Bell-Krotoski JA. "Pocket" filaments and specifications for the Semmes-Weinstein Monofilaments. J Hand Ther, 1990; Jan-Mar: 26-31.

58 Birke JA, Sims DS. Plantar sensory threshold in the ulcerative foot. Lepr Rev, 1986; 57: 261-7.

59 Steenbergen GJ, Pfaltzgraff RE. Treatment of neuritis in borderline leprosy-a pilot trial. Lepr Rev, 1975; 46: $115-8$.

60 Parkhe SM, Smith WCS, Samson PD, Solomon M. Sudden paralysis associated with multi-drug therapy-a cautionary tale. Quad Coop San, 9: 380 (abstracts of the 13th International Leprosy Congress '88).

61 Groenen G, Janssens L, Kayembe T, Nollet E, Coussens L, Pattyn SR. Prospective study on the relationship between intensive bactericidal therapy and leprosy reactions. Int $J$ Le pr, 1986; 54: 236-44.

62 Brunel W, Schecter WP, Schecter G. Hand deformity and sensory loss due to Hansen's disease in American Samoa.

63 Magora A, Sheskin J, Sagher F, Gonen B. The condition of the peripheral nerve in leprosy under various forms of treatment. Int J Lepr, 1970; 38: 149-63. 